\title{
Proposal of a fertility index of Hypnea for ecophysiological studies
}

Propuesta de un índice de fertilidad de Hypnea para estudios ecofisiológicos

\section{Taiara Aguiar Caires ${ }^{1,2}$, Mara Rojane Barros de Matos $^{3}$, Goia de Mattos Lyra ${ }^{1,2}$, José Geraldo de Aquino Assis ${ }^{4}$ and José Marcos de Castro Nunes ${ }^{2,3}$}

\begin{abstract}
${ }^{1}$ Programa de Pós Graduação em Botânica da Universidade Estadual de Feira de Santana (PPGBot-UEFS), Departamento de Ciências Biológicas, Av. Universitária, s/n. 44031-460, Feira de Santana, Bahia, Brasil. taiaracaires@gmail.com

${ }^{2}$ Laboratório de Algas Marinhas (LAMAR), Departamento de Botânica, Instituto de Biologia, Campus de Ondina, CEP 40210-730, Universidade Federal da Bahia, Salvador, Bahia, Brasil

${ }^{3}$ Universidade do Estado da Bahia, Departamento de Ciências Exatas e da Terra, Campus II, Rodovia Alagoinhas/Salvador, Br $110 \mathrm{Km} \mathrm{03,} \mathrm{Alagoinhas,} \mathrm{Bahia,} \mathrm{Brasil}$

${ }^{4}$ Laboratório de Genética Vegetal (LAGEV), Departamento de Biologia General, Instituto de Biologia, Campus de Ondina, CEP 40210-730, Universidade Federal da Bahia, Salvador, Bahia, Brasil

Abstract.- Few studies of natural populations of the red algae Hypnea musciformis have been conducted. To enhance our knowledge, it would be helpful to define methodologies that explore the species' adaptability to different environments and seasons. Tetrasporophyte is the most frequent reproductive stage in this species. A case study of 2 populations in the Brazilian tropics allowed us to define a fertility index based on the meiotic count of tetrasporangia. Significant differences were found in the production of tetrasporangia among microhabitats and between the dry and rainy seasons. The analysis of this index in red algae may constitute an important tool for understanding the biology and ecology of this algal group.
\end{abstract}

Key words: Fertility, Hypnea, tetrasporangia, Brazil

\section{INTRODUCTION}

The Phylum Rhodophyta includes some species of great economic importance because they are phycocolloids sources used in pharmaceuticals, cosmetics, textiles, and food industries (Schenkman 1989, Bravin \& YoneshigueValentin 2002, Reis et al. 2008). Among them, Hypnea musciformis (Wulfen in Jacquin) J. V. Lamouroux 1813 represents one of the natural sources of the polysaccharide $k$-carrageenan, and is widely distributed along the coast of Bahia, the Brazilian state with the longest coastline. The coast is $1103 \mathrm{~km}$ long and presents great richness and diversity of environments, which support a broad diversity of marine flora (Nunes \& Guimarães 2008).

Studies of natural populations of this species are scarce, and large gaps are present in our knowledge of its biology and ecology. Thus, it is important to define methodologies that contribute to our understanding of the species' adaptability to different environments and seasons. In other groups of plants, estimating the fertility rate is an effective technique to evaluate the relationship between reproduction and different environmental conditions. Day et al. (1988) used a fertility index that was related to biomass and disorder in populations of higher plants on the swampy edges of a river in Canada. Estrabou et al. (2004) defined a fertility index based on spore counting per apothecium in lichens, relating it to the degree of pollution in different areas in Argentina. Engel \& Destombe (2002) conducted an experiment on the French coast with the Rhodophyta species Gracilaria gracilis (Stackhouse) M.Steentoft, L.M.Irvine, \& W.F.Farnham 1995, by using a fertility index based on the number of cystocarps by length of the stem. The authors compared this index between specimens that had been collected in pools with different hydrodynamics, in order to determine differences in the fertilization rates.

In order to understand the adaptive strategies of Hypnea musciformis, a study was conducted using natural populations of the species found on the beaches of Stella Maris and Itacimirim (Bahia, Brazil). As the tetrasporophyte has been shown to be the most frequent reproductive stage of this species in Brazil (Mshigeni 1976, Schenkman 1989, Reis \& Yoneshigue-Valentin 1998, 2000), we defined a meiotic fertility index based on the number of tetrasporangia. The index was compared between populations on the two beaches in microhabitats and at different periods of the year. This fertility index is an important tool for ecological studies in this study group and can contribute significantly to our knowledge of the biology and ecology of $H$. musciformis in Brazil. 


\section{MATERIAL AND METHODS}

Samples were collected from 2 populations of Hypnea musciformis on different beaches in Bahia, Stella Maris

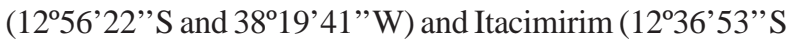
and $\left.38^{\circ} 02^{\prime} 31^{\prime \prime} \mathrm{W}\right)$, which are located in the cities of Salvador and Camaçari, respectively (Fig. 1). In this region, the species aggregate to form banks on the reef formations.

Bahia is located in the tropical zone of Brazil and has two typical seasons or periods, a dry season that occurs between September and February and a rainy season from March to August. The climate in this region varies from wet to sub-humid, with air temperatures ranging from 14 to $33^{\circ} \mathrm{C}$ and seawater from 20 to $27^{\circ} \mathrm{C}$ (Maida \& Ferreira 1997).

The sampling period occurred between August 2007 and July 2009. We collected a total of eight samples, one at the beginning and one at the end of each season. These periods are referred to as Rainy 1 (R1) and Rainy 2 (R2), signifying the beginning and end the rainy period, respectively, and Dry 1 (D1) and Dry 2 (D2), which were samples collected at the beginning and end of the dry period, respectively (Table 1). Samples were taken in the intertidal zone, during low spring tide. The reefs were divided into microhabitats based on their hydrodynamics according to Nunes \& Paula (2002): Tidal Pools (TP),

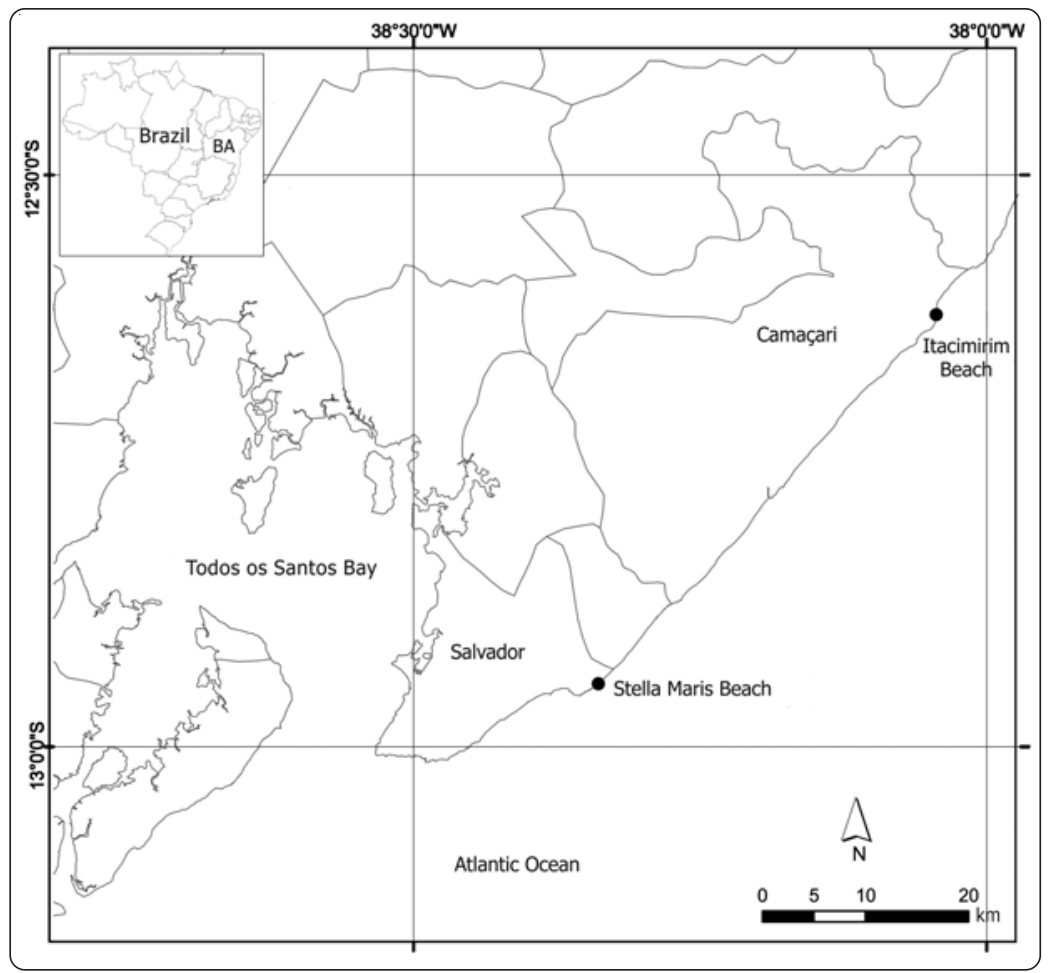

Figure 1. Map showing the locations of the study areas, Stella Maris (Salvador) and Itacimirim (Camaçari), beaches, Bahia, Brazil. BA: Bahia / Mapa de localización del área de estudio: Playas Stella Maris (Salvador) e Itacimirim (Camaçari), Bahia, Brasil. BA: Bahia 
(ethanol:acetic acid, 3:1) and after $24 \mathrm{~h}$, were transferred to $70 \%$ alcohol to complete the fixation process. The fixed fragments were macerated and distended on slides, stained with Wittman (iron hematoxylin), and then heated to highlight the tetrasporangia. We created slides of 480 tetrasporic individuals, 10 from each microhabitat sampled. Each slide was divided into 10 identical quadrants, of which 5 were randomly chosen and the tetrasporangia in them were counted. In each of the chosen quadrants, 200 cells were counted to determine the ratio of vegetative to meiotic cells, resulting in a total of 1000 cells per slide. The results are expressed as mean \pm standard deviation.

The $t$ test and the analysis of variance (ANOVA) were used to verify significant differences in the fertility index of $H$. musciformis samples taken from different microhabitats and the variation in this index over the sampled periods. The data were transformed into logarithms and the confidence level for all tests of significance was set at $95 \%(P=0.05)$. The Kolmogorov $\&$ Smirnov test was used to test the normality of the observed distribution. Variances were tested for homogeneity by using Bartlett's test (Zar 1999). For comparison of multiple means, the Tukey-Kramer test (parametric) (Zar 1999) was applied. Analyses were performed using GraphPad Software for Windows version 3.06 (2003).

\section{Results AND Discussion}

The analysis of the fertility index of Hypnea musciformis taken from different microhabitats showed that the population of $H$. musciformis from the frontal region of the reef (FRR) produced a greater amount of tetrasporangia, with an average of 5.6 tetrasporangia/1000 vegetative cells. The TP showed low production, approximately 4.2 tetrasporangia/1000 vegetative cells, and the PRR showed an intermediate value of 4.9 tetrasporangia/1000 vegetative cells. Although the FRR was associated with high tetrasporangia production, the differences among the habitats in tetrasporangia production were not significantly different $(P>0.05)$.

Although the overall values of tetrasporangia production in both beaches revealed no significant differences $(P>0.05)$, the analysis of the production in each beach showed differences between microhabitats depending on whether it was the dry or rainy season. For the Stella Maris beach, in the rainy season, extremely significant differences were observed between the TP and PRR microhabitats $(P<0.001)$ and between the TP and FRR microhabitats $(P<0.001)$, and a very significant difference was observed between the PRR and FRR microhabitats $(P<0.01)$. In the dry season, the TP and PRR microhabitats $(P<0.05)$ and the TP and FRR microhabitats $(P<0.05)$ differed significantly. For the Itacimirim beach, no significant differences were found in tetrasporangia production between the microhabitats during the dry season. In the rainy season, a very significant difference was observed between the PRR and FRR microhabitats $(P<0.01)$ only.

Significant differences in the fertility of the populations of the 3 microhabitats may be directly related to the specific conditions of each environment. The front of the reef may have shown higher production of tetrasporangia due to more turbulent hydrodynamics in this microhabitat, which increases the probability that gametes will encounter one another, even when the tide is low (Engel \& Destombe 2002). The situation is different in the TP regions, where the water stagnates, and also in the PRR, which is completely immersed during periods of low tide.

Fertilization in red algae is directly influenced by water movement, because this group uses spermatia (lacking flagella). Instead, the gametes are carried passively by water until they reach the carpogonia (Lee 1999). Searles (1980) reported that environments with greater water movement might be advantageous, because they facilitate the meeting of gametes in red algae, and thus, algae in environments with calmer waters may be at a disadvantage. In a study of the red algae Gracilaria gracilis, Engel \& Destombe (2002) showed that individuals in regions with less turbulent hydrodynamics had lower fertilization rates than those in environments with greater water movement. The development of the tetrasporic phase is entirely correlated with the rate of fertilization and the consequent formation of carposporophytes. During this last phase, the zygote amplifies (Searles 1980) from a single syngamy event, undergoing successive mitotic division to form carpospores and giving rise to the tetrasporic phase. This amplification compensates for the lack of mobile gametes in this group. In addition to the greater movement of water, the stability in the frontal region of the reef is another factor that may increase the production of tetrasporangia. In this environment, populations do not suffer the stress of desiccation cycles, which affect the protected region of the reef. In addition, the populations are not subjected to changes in temperature, salinity, and the rate of incidence of light rays, which occur in tidal pools (Reis \& Yoneshigue-Valentin 1998, 2000). 
The difference in tetrasporangia production between the dry and the rainy periods was more evident on the beach of Itacimirim, in all microhabitats. At Stella Maris beach, only the tidal pools did not show a significant difference in tetrasporangia production for different seasons (Table 2). This analysis revealed that the differences are clearer in comparisons performed using values obtained in the same period of the year than in different periods (Fig. 2).

The analysis of tetrasporangia production in different periods showed significant differences, especially during the rainy period, between the sample taken at the beginning and that taken at the end of the period (Fig. 2). Highly significant differences were observed during the rainy period in tetrasporangia production in all three microhabitats of the two beaches, with the exception of the Stella Maris TPs. Between the beginning and end of the dry period, no significant differences were observed in tetrasporangia production at the Stella Maris microhabitats. At the Itacimirim beach, the ending values of only the TP and PRR areas differed significantly from their beginning values, showing a consistency in tetrasporangia production during this period (Table 2).
Table 2. Statistical analysis of the production of tetrasporangia in microhabitats at the beaches of Stella Maris and Itacimirim, as a function of the availability of rain. R1 and R2: beginning and end of the rainy period, respectively; D1 and D2: beginning and end of the dry period, respectively. TP: tidal pool; PRR: protected reef region; FRR: front reef region. NS: difference not significant / Análisis estadísticos de la producción de tetrasporangios en los microhábitats de las playas Stella Maris (Salvador) e Itacimirim (Camaçari) en función de la lluvia. R1 y R2: principio y final de la temporada de lluvias, respectivamente; D1 y D2: principio y final de la temporada seca, respectivamente. TP: poza intermareal; PRR: región intermareal protegida del oleaje; FRR: región intermareal expuesta al oleaje. NS: ninguna diferencia significativa

\begin{tabular}{lccc}
\hline \multirow{2}{*}{ Beaches } & \multicolumn{3}{c}{ Sampling periods } \\
\cline { 2 - 4 } Stella Maris & $\mathrm{R} 1 \times \mathrm{R} 2$ & $\mathrm{D} 1 \times \mathrm{D} 2$ & Rainy $\times$ Dry \\
& $\mathrm{TRR}(P<0.001)$ & $\mathrm{NS}$ & $\mathrm{TP}(\mathrm{NS})$ \\
& $\mathrm{FRR}(P<0.01)$ & $\mathrm{NS}$ & $\mathrm{PRR}(P<0.01)$ \\
& $\mathrm{TRR}(P<0.05)$ \\
Itacimirim & $\mathrm{TP}(P<0.001)$ & $\mathrm{TP}(P<0.05)$ & $\mathrm{TP}(P<0.001)$ \\
& $\operatorname{PRR}(P<0.001)$ & $\mathrm{PRR}(P<0.001)$ & $\operatorname{PRR}(P<0.001)$ \\
& $\mathrm{FRR}(P<0.001)$ & $\mathrm{FRR}(\mathrm{NS})$ & $\mathrm{FRR}(P<0.001)$ \\
\hline
\end{tabular}

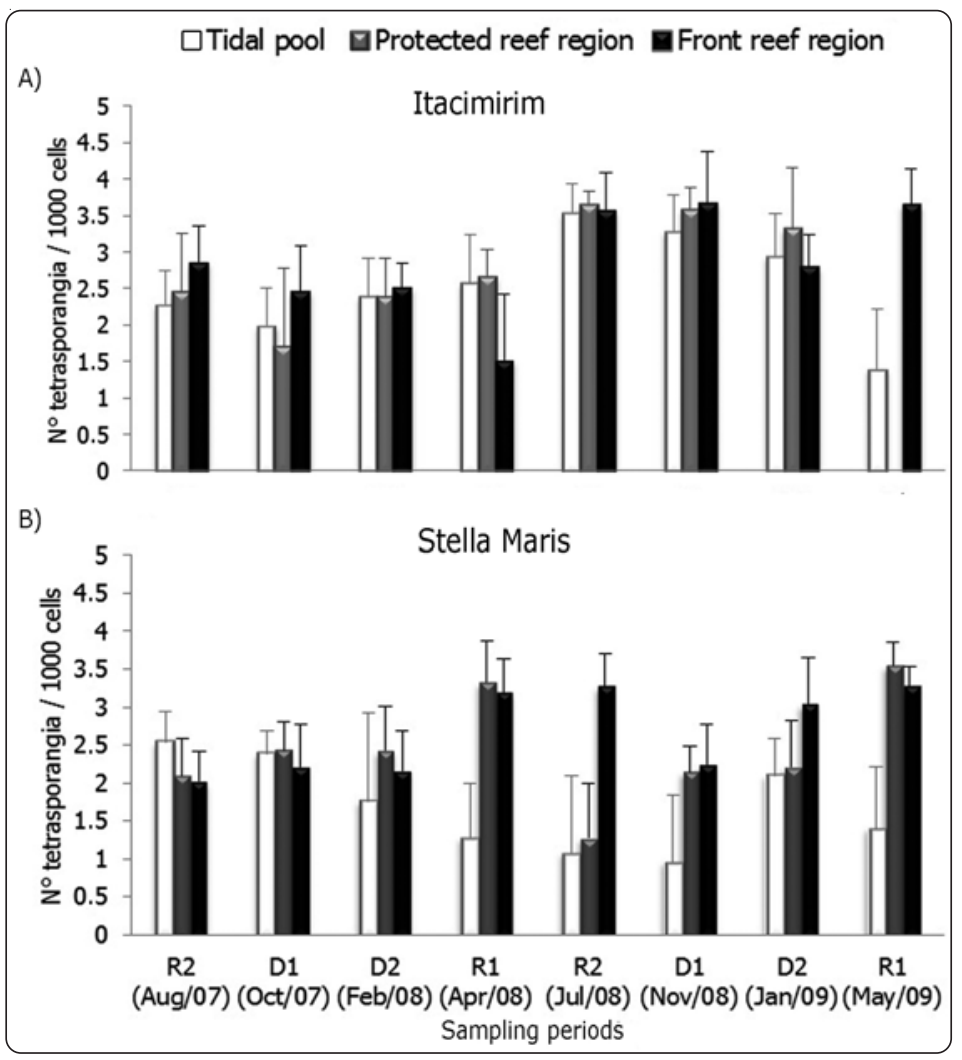

Figure 2. Graphical representation of the mean ( $\pm S D$ ) of tetrasporangia production in Hypnea musciformis at microhabitats as a function of rain on the beaches of Stella Maris (Salvador) (A) and Itacimirim (Camaçari) (B), Bahia, Brazil. R1 and R2: beginning and end of the rainy period, respectively; D1 and D2: beginning and end of the dry period, respectively / Representación gráfica de la media $( \pm \mathrm{DE})$ de la producción de los tetrasporangios de Hypnea musciformis en los microhábitats en función de la lluvia en las playas Stella Maris (Salvador) (A) e Itacimirim (Camaçari) (B), Bahia, Brasil. R1 y R2: principio y final de la temporada de lluvias, respectivamente; D1 y D2: principio y final de la temporada seca, respectivamente 
Reproductive adaptation to environmental conditions was evident, especially within the same period, showing the influence of rainfall on the reproductive ecology of $H$. musciformis. The rainy period has wide variation in rainfall, which may have altered the salinity and temperature. The rainfall increases the strength of water movement due to the strong winds that accompany it, and it also increases water turbidity. The increase in turbidity can disrupt the meeting of gametes due to the large amount of particulate matter originating from the turning of the sediment. The dry period showed constant production of tetrasporangia, probably because changes in abiotic factors were small.

The presented case study suggests that the use of the meiotic index in red algae may constitute an important tool in elucidating the biological and ecological behavior of the species. As this is a species of great economic importance, these analyses can provide the basis for future $H$. musciformis cultivation studies.

\section{ACKnowledgments}

To Mariana Athayde and Brendan Lee for reviewing the English text. Support for this study provided by CNPq (Conselho Nacional de Desenvolvimento Científico e Tecnológico) and FAPESB (Fundo de Amparo à Pesquisa do Estado da Bahia) with scholarships granted to the first author through PIBIC (Programa Institucional de Bolsas de Iniciação Científica) and to Mariana Athayde and Brendan Lee for reviewing the English text.

\section{LITERATURE CITED}

Bravin IC \& Y Yoneshigue-Valentin. 2002. Influência de fatores ambientais sobre o crescimento in vitro de Hypnea musciformis (Wulfen) Lamouroux (Rhodophyta). Revista Brasileira de Botânica 25: 469-474.

Day RT, PA Keddy, J McNeill \& T Carleton. 1988. Fertility and disturbance gradients: a summary model for riverine marsh vegetation. Ecology 69: 1044-1054.

Engel CR \& C Destombe. 2002. Reproductive ecology of an intertidal red seaweed, Gracilaria gracilis: influence of high and low tides on fertilization success. Journal of Marine Biological Association of the United Kingdom 82: 189192.
Estrabou C, L Stiefkens, M Hadid, JM Rodríguez \& A Pérez. 2004. Effects of air pollutants on morphology and reproduction in four lichen species in Córdoba, Argentina. Ecología en Bolivia 39: 33-45.

Lee RE. 1999. Phycology, 614 pp. Cambridge University Press, Cambridge.

Maida M \& BP Ferreira. 1997. Coral reefs of Brazil: an overview. Proceedings of the 8th International Coral Reef Symposium 1: 263-274.

Mshigeni KE. 1976. Studies on the Reproduction of Selected Species of Hypnea (Rhodophyta, Gigartinales) from Hawaii. Botanica Marina 19: 341-346.

Nunes JMC \& SMPB Guimarães. 2008. Novas referências de rodofíceas marinhas para o litoral brasileiro. Biota Neotropica 8: 89-100.

Nunes JMC \& EJ Paula. 2002. Composição e distribuição das Phaeophyta nos recifes da região metropolitana de Salvador, Bahia, Brasil. Iheringia 57: 113-130.

Reis RP \& Y Yoneshigue-Valentin. 1998. Variação espaçotemporal de populações de Hypnea musciformis (Rhodophyta, Gigartinales) na Baía de Sepetiba e Armação dos Búzios, RJ, Brasil. Acta Botanica Brasilica 12: 465483.

Reis RP \& Y Yoneshigue-Valentin. 2000. Phenology of Hypnea musciformis (Wulfen) Lamouroux (Rhodophyta, Gigartinales) in Three Populations from Rio de Janeiro State, Brazil. Botanica Marina 43: 299-304.

Reis RP, Y Yoneshigue-Valentin \& CP Santos. 2008. Spatial and temporal variation of Hypnea musciformis carrageenan (Rhodophyta- Gigartinales) from natural beds in Rio de Janeiro State, Brazil. Journal of Applied Phycology 20: 18.

Schenkman RPF. 1989. Hypnea musciformis (Rhodophyta): Ecological influence on growth. Journal of Applied Phycology 25: 192-196.

Searles RB. 1980. The strategy of the red algal life history. The American Naturalist 115: 113-120.

Zar JH. 1999. Biostatistical analysis, 663 pp. Prentice-Hall, Englewood Cliffs. 